\title{
How do we work with medical teams to provide optimal treatment for clients in the acute medical environment?
}

\author{
Lisa Stokes", Michael Bruce \\ From 2014 ANZAED Conference: Driven Bodies Driven Brains \\ Fremantle, Australia. 22-23 August 2014
}

Historically, there have always been medically unwell clients with eating disorders whose pathway of care involves presentations and admissions to emergency departments, intensive care units and/or medical/surgical units. At the Royal Melbourne Hospital there has been a noted increase in not only the number of clients requiring admissions to medial units, but also in the severity in medical acuity of these clients.

Lack of clinical expertise in the acute health sector can result in delayed or sub optimal treatment, increased length of stay and poorer client outcomes.

This paper will outline a new initiative proposed at the Royal Melbourne Hospital involving the collaboration of Consultation Liaison Psychiatry, Specialist Services Eating Disorders Program and an Acute Medical Unit. The aim of this project is to support staff in the acute health sector, particularly nurses, in their understanding of the psychopathology of eating disorders, to improve clinical skills and provide timely and appropriate interventions to clients and their families.

The core of this project is the development of an E-learning package, specific to the detection, assessment management and ongoing care of clients with eating disorders in the acute health sector.

This abstract was presented in the Service Initiatives stream of the 2014 ANZAED Conference.
Published: 24 November 2014

doi:10.1186/2050-2974-2-S1-O25

Cite this article as: Stokes and Bruce: How do we work with medical teams to provide optimal treatment for clients in the acute medical environment? Journal of Eating Disorders 2014 2(Suppl 1):O25.

* Correspondence: lisa.stokes@mh.org.au

Royal Melbourne Hospital, Melbourne, Australia

Submit your next manuscript to BioMed Central and take full advantage of:

- Convenient online submission

- Thorough peer review

- No space constraints or color figure charges

- Immediate publication on acceptance

- Inclusion in PubMed, CAS, Scopus and Google Scholar

- Research which is freely available for redistribution
() Biomed Central 